\title{
The non-English major lecturers speak English: The barriers encountered by adult learners
}

\author{
Ahmad Madkur \\ ahmadmadzkur@metrouniv.ac.id \\ State Islamic Institute (IAIN) Metro, Lampung \\ Jl. Ki Hajar Dewantara No. 14 Iring Mulyo, Kota Metro, Lampung
}

Received: May 15, 2017;

Accepted: February 8, 2018;

Published: March 2, 2018

\begin{abstract}
This study was aimed at investigating the difficulties and problems faced by non-English major lecturers when they were taking a part in English discussion. This study was a qualitative descriptive research involving 10 non-English major lecturers who took a part in a twice-a-week discussion so-called English Corner. To collect the data, in-depth interview and observation were used. The collected data were analyzed by using Miles and Huberman's interactive data analysis data model consisting of data reduction, data display and data verifying. The result of the study showed that those barriers could be classified into three problems namely socio-cultural, linguistic and interpersonal problems. The found barriers were expected to be a consideration to find out the solution to make the betterment of English learning among lecturers with the non-English background of study.
\end{abstract}

Keywords: adult learners, English speaking, learning barriers, speaking skill, non-English major lecturer

How to cite this paper: Madkur, A. (2018). The non-English major lecturers speak English: The barriers encountered by adult learners. Journal on English as a Foreign Language, 8(1), 39-56 (doi: 10.23971/jefl.v8i1.584)

DOI: http://dx.doi.org/10.23971/jefl.v8i1.584

In Indonesia, English is one of a number of foreign languages which have been in use for some time or which are coming to be taught. These include Dutch, Arabic, English, German, French, Japanese, and latterly, Chinese (Lauder, 2010, 
p. 13). However, it seems that English is a very special subject since it is taught from elementary school to university level. In university level, not only the students majoring English are required to master English but also those majoring non-English are also required to learn it for at least two semesters. The age of its learners is also diverse; children, teenagers and even adult. This study was focused on adult learning commonly called andragogy.

The term andragogy, as elaborated by Knowles, came when the adult education started to organize systematically during 1920s (Grasso, 2017). At that time, the teachers of adults began finding the pedagogical model difficult to implement in teaching the adults. Since then, Knowles had already begun constructing a comprehensive theory of adult learning that is attached to the characteristics of adult learners. The andragogical model he established based on several assumptions differed from the acknowledged pedagogical models.

In the field of education, Cozma (2015, p. 1210) state that there is a common myth that adult students are generally more ineffective as language learners than the traditional students, on the account that the younger people are, the more flexible their brains, and, consequently, the better their cognitive functions. In the context of English learning, the adult learners usually face problems when they learn how to speak English. Therefore, the teachers must pay a big attention to the use of method and strategy.

The fact that English is needed for a variety of purposes, whether academic or non-academic, also attracts some non-English major lecturers' attention in State Islamic Institute (IAIN, previously known as STAIN Jurai Siwo) Metro. They are lecturers in some departments such as Arabic Language Teaching (PBA), Akhwalusy Syakhsiyyah (Islamic Law), Islamic Education department (PAI), Sharia Economics and some others. Despite their relatively old age and their full schedule of teaching and other academic activities, they showed big enthusiasm and willingness to learn English especially speaking skill.

These adult learners preferred to focus on speaking to other basic English skills because most of them want to be able to communicate their ideas in some events such as seminar and conference to other people not only in Indonesia but also overseas countries. This is in line with what Ahmad (2016, p. 479) states that English is not only the link language within a country but abroad also. People of one country are able to share and appreciate the ideas of the people of another country through English.

This condition makes me interested and motivated to be a part of their learning English. I have been joining this forum since it was established. Nevertheless, teaching English to adult learners is not "a piece of cake" thing. Though they had already experienced learning English, a very limited 
interaction using English causes them find English very complex to master. The forum conducted two meetings in a week and in each week there werealways one or two participants who were absent. As far as I was concerned, they encountered several obstacles especially when trying to speak English. This study was therefore conducted to investigate the barriers encountered by nonEnglish major lecturers in the process of learning English particularly speaking skill. The result of this study is expected to beneficially contribute for those who teach English adult learners so that the andragogy teachers could know the adult learners' problems and subsequently find the solutions to minimize the problems. In addition, it is expected that the institution considers making a policy related to the betterment of andragogy instruction.

Not as popularly known as pedagogy, andragogy was initially invented by the German educator Alexander Kapp in 1833 (Knowles as cited in Chinnasamy, 2013) and it was developed as an adult education theory by Malcolm Knowles, an American educator. The term 'andragogy' is derived from Greek words meaning "man-leading" and it differs from pedagogy which means "child-leading". Adult learners are a diverse group, typically age 25 and older, with a wide range of educational and cultural backgrounds, adult responsibilities and job experiences. They typically do not follow the traditional pattern of enrolling in postsecondary education immediately after high school.

To more understand the practice of andragogy, it is urgent to know its principles. The first proinciple is 'they need to know'. Knowles as cited in Rismayanto and Suryani (2017) states that "Adults need to know why they need to learn something before undertaking it." When learning on their own, adult learners spend a plenty of energy and time trying to understand the value of the new learning; either the benefit from learning or the consequence of not learning. The adult learners are different from young learners who are usually easier to be asked to learn something. In fact, the adult learner needs either to be told or, even better, to be led to discover why certain knowledge is worth learning. Therefore, the materials prepared for them should be clearly conveyed in order to meet their needs on learning English.

Based on this principle, information literacy curriculum that is focused on the adult learner needs to be relevant, applicable, and have a real-life focus (Knowles, Holton, \& Swanson, 2005, p.147). It should also be problem-based so that the students understand why they are learning something. Problem-based instruction can also help push the student to be a more self-directed learner. An example of problem-based instruction in an information literacy course is to give the students a scenario where they need to find information. The students 
then determine what they already know and then seek out new ways to find the information to solve the problem given in the scenario.

The second principle is 'the learner's self concept'. Andragogy emphasizes that adults have a need to be self-directing; unfortunately, it is often seen that they see this need being unfulfilled when taking a part in education. In other words, when deciding what they really need themselves, they also sometimes have no idea what is best for them. In this condition, the instructor's role is highly important for analyzing their needs and then guiding them in that field. The autonomy in self-determination is defined as a desire to be the origin and cause of their behavior. The adult learning program is required to pay attention to this nature of adult learners. However, this does not mean that the adult learners are given chance to be individual. The instructors must keep involving them in interactive activities while respecting their self-concept, meaning that there is no a kind of stressing to follow every single instruction. For example, when an adult learner finds it difficult to master English vocabularies by memorizing, they should not be forced to memorize every single vocabulary.

The third principle is 'role of the learner's experience'. Adult learners have a lot of experience and their experience is more diverse than children's. As a consequence, the learner's experience is a valuable resource in the classroom. This principle is actually not directly interrelated to motivation as the other principles. Nevertheless, if this principle is ignored, there will be considerable impact on an adult learners' motivation. Many times, if the classroom activities completely have no connection with their prior experience or knowledge, they become uninterested and finally less motivated. Knowles, et al. recognize that children have experience as well, but the relationship between the adult and their experience is different than the relationship between the child and their experience. Unlike a child's identity tends to come from social contacts, e.g. family, school, or sports teams, an adult originates self-identity from their experiences. In the context of learning, the adult learners' backgrounds such as education and occupation are included in the aspects of material selection that match to them.

The fourth principle is 'readiness to learn'. While learning, adults always want to get something useful for and suitable for their lives. The contexts of lifedemands push adults to highlight dissimilar learning at different points. Adults are "ready to learn those things they need to know and be able to do in order to cope effectively with their real-life situations." (Knowles as cited in Noor, Harun, \& Aris, 2012). Andragogy suggests that real-life situations are major, contextual situations. Their thinking is also more critical that they can criticize the materials given by the instructors. This principle should inspire the instructors to provide materials that fit the adult learners' needs. To make an

Journal on English as a Foreign Language, 8(1), 39-56

Copyright (C) 2018 by JEFL, p-ISSN 2088-1657; e-ISSN 2502-6615 
example, a student majoring banking would be very enthusiastic to learn some English terms used in the field of banking. In the context of this study, the lecturers' expertise on education would also be more attracted in learning the topics related to their fields.

The fifth principle is 'orientation to Learning'. Adults come to learn English because of the existence of a problem they want to solve, not because they just like English. Aydin and Yildirim (2017) found that the problemsolving strategies were the most favored strategies done by intermediate-level adult learners in their foreign language reading class. Adult learners, in the concept of andragogy, are life-problem or task-centered in their approach to learning. There are three orientations that have been suggested, but they are overall the same. In fact, they arguably build on each other: task-centered would be considered most effective if the task is appropriate to an essential problem, and problem-centered would be most motivating when that problem is a life issue, rather than a trivial issue. Andragogy considers all three of these orientations likely for adults, and a fourth orientation, content-focused, more likely for children. Knowles as cited in De Vito (2009) stresses the significance of orientation to learning by relating the poor impact of reading programs that were disconnected from life experiences and life problems and the powerful impact of those same programs after the administrators linked them to the learners' context.

The last principle is 'motivation to learn'. Like young learners, the adults' learning is also influenced by their motivation both internally and externally. However, in some ways, the motivation is different. What this principle assumes is that "even though adult learners are receptive to some external motivators such as better jobs, promotions, and higher salaries, the strongest motivators are internal pressures, like the desire for better job satisfaction, selfesteem, and quality of life" (Knowles et al., 2005, p. 68). Furthermore, according to Igoudin (2008, p. 1), the adult students viewed language education as a necessary transitional path towards integration and attainment of a desired identity. Meaning to say, the adult learners perceive of English' role in bridging themselves to their wanted identity. The instructors of adult learning program should benefit this to always keep them motivated. Motivation significantly influences the learners' comprehension of something they learn.

It is not too exaggerated to say that speaking, among other basic skills of English, is an essential skill. Without ignoring the importance of other skills such as listening, reading and writing, someone is generally considered good in English if he/she is able to speak English well. Regarding the definition of speaking, Thornbury $(2005$, p. 20) remarks that speaking is a communicating real-time activity to direct meaning in the interaction with others. However, the 
teacher must notice that in EFL context the students infrequently try to produce their foreign language because they are aware of the gaps in their knowledge. A speaker necessitates devotion to precise details of the language. She he needs to invent the correct words and the accurate grammar to convey meaning precisely and also need to establish the discourse so that a listener will understand.

Furthermore, Brown (2001) elaborates that the ability to speak a language means that he/she can conduct a conversation realistically proficiently. According to Thornbury (2005), as an interactive skill, speaking requires the ability to have connections with the other aspects of language. Speaking skill needs to be developed and practiced independently from the other aspects of language, such as grammar and listening. In that case, the teaching and learning process will be as interesting as possible to be conducted in each classroom in order to make the students become more attracted in learning the other aspects of language.

To teach speaking, four aspects must necessarily be considered (Brown, 2001). They are fluency, accuracy, pronunciation, and vocabulary. Fluency is when the speaker needs to know where she he has to pause and stop hisher speaking in an appropriate place. Accuracy deals with the grammatical structures which cover some aspects like part of speech, tense, phrase, sentence, etc. Pronunciation goals focus on elements that enhance communication which will cover stress pattern, intonation, voice quality, etc. Then vocabulary becomes a very important part of language learning which can use to determine students can speak fluently or not.

Despite the importance of speaking a foreign language for adult learners, they have experienced many difficulties and problems when pursuing ESL learning, regardless some advantages they may have over children $(\mathrm{Wu}, \mathrm{Wu}, \&$ Le, 2014, p. 1132). In the case of speaking skill, Bailey (2006, p. 114) elaborates that there four key groups that need to understand the issues related to and challenges faced by adults lacking English-speaking skills. These groups are (a) policymakers who affect the design, funding, and evaluation of adult English programs; (b) researchers who examine the success of adult education programs; (c) educators who organize teachers to work with adult learners; and (d) the teachers themselves.

At IAIN Metro, the English Corner consisting of the lecturers nonEnglish major was still new and not many took a part because of some reasons. Even though a small group, it created a good atmosphere of English learning of adult learners in this institute. The objective of this research was to find out the barriers faced by the lecturers of non-English major joining in the forum. 
This study was significant because it could give a brief description of obstacles faced by the adult learners especially the lecturers who were willing to improve their English speaking ability to support their academics. Furthermore, the result of this study was expected to be one of considerations for the policy maker at this institute to make a policy that support the English learning for adult learners, in this case, the lecturers.

\section{METHOD}

This study was a descriptive qualitative research aiming to investigate the barriers faced by adult learners, in this case, lecturers, of English. It was conducted in IAIN Metro Lampung. The subject of the research was those who are non-English major lecturers and who regularly participated the discussion forum called English Corner. The participants of this study were ten lecturers, aged from 36-60 year old, of non-English majors. They were three lecturers of Arabic Language Teaching (PBA) department, two lecturers of Akhwalusy Syakhsiyyah (Islamic Law) department, two lecturers of Islamic Teaching (PAI) department, one lecturer of Elementary School Education department, one lecturer of Islamic Economy department, and one lecturer of $D a^{\prime} w a h$ department. To gain the data, the writer conducted observation in six meetings of the forum. The observation was to see the difficulties when they were speaking English in English Corner. Then to make sure the data gotten in the observation, the interviews were also administered to know the difficulties from the lecturers' perception.

After the data were collected, Miles and Huberman model. At first, the collected data were reduced by summarizing and choosing the specific part of the data that meet the research questions. Then after the data reduction, the data were displayed by narratively describing the difficulties of the lecturers. At last the writer made the data verification by making conclusion of the data findings.

\section{FINDINGS}

\section{The Difficulties Faced by Non-English Major Lecturers in English Discussion} Learners' Perception

Adult learners' or non-English major lecturers' perception could very possibly five impacts on his her motivation in learning. Thus, it is important to know their perception on a subject that they are learning. In this case, the lecturers were asked a question "what do you think about English?" Despite their non-English majors, they all agreed that English is an important language that needs to be mastered. A participant, who has gained his doctoral degree in wakaf, S, stated 
"English for me is a tool to broaden my knowledge. If I may say I am actually regretful that I am late to start learning English"

This participant's opinion showed that even though their educational background and the subject they teach were not English or other subjects related to English, they perceived that English is an important language.

\section{Adult learners' Motivation}

Frequent studies have revealed that motivation is positively connected to success in learning the English language or any other second language. In general, motivation and attitude work together to ensure learners' successful acquisition of a second language; hence, various motivational theories and models have been formulated to examine and explain this connection. "Motivation represents one of the most appealing, yet complex variables used to explain individual differences in language learning" (MacIntyre, 2001, p. 462). The early attempt to understand the impact of motivation on English language learning stems from the field of social psychology. Since it is not easy to improve the learners' motivation, (Al Othman \& Shuqair, 2013, p. 123-130) conducted a research where they guided Kuwaiti teachers in appreciating better the attitude and motivation of their students and to look for a suitable approach to teaching the English language.

In this study, the participants showed their motivation in learning English. It could be seen from their attendance; even though this forum is informal in which there is no punishment if they did not present, they came to the forum with at least $70 \%$ of the meetings. In addition, in the process of discussion, they looked enthusiastic and active in taking a part by asking questions or expressing opinion although again and again some of them still combined English and Bahasa Indonesia. As far as I am concerned, some lecturers have already shown a significant progress because of their high participation and their motivation.

To illustrate their motivation, one of the lecturers, $\mathrm{K}$, really surprised me as the instructor since she was the oldest participant in the forum. When asked about the reason of her joining this forum, she stated that "saya gak tau alasan pastinya, tapi saya merasa harus bisa bahasa Inggris karena kedepan seorang dosen harus bias ngomong bahasa ini". Even though her ability, if I may say, was the lowest one, she was almost never absent in this forum, even very often managed the schedule and place when there was a schedule change. In addition, she was the most active participant in following the classroom activities. This positive attitude really brought her to the stage where she was now getting better in term of vocabulary and speaking. 


\section{The Problems Faced by Non-English Major Lecturers in English Discussion Problems of Linguistics}

In language pedagogy and andragogy, figuring out linguistics difficulties is needed since it can help teachers find an appropriate teaching strategy. Furthermore, by knowing the students' difficulties, the teachers can decide to prioritize what material should be taught first and more intensively. In this study, the linguistic difficulties encountered by the lecturers were lack of vocabularies and interference of Indonesian language into English. For example, when asked to talk about unforgettable moment of first teaching, NY said,

"I am happy...I spirit to teach. But,...I, gerogi and I am forget beberapa materi hehe. Student I give one pertanyaan. But, I do not know, so I say, it is homework my. Next class, I want to tell about it to you all"

NY spoke slowly and his sayings contained two Indonesian words namely gerogi (nervous) and pertanyaan (question). The interference of grammatical aspect also appeared in this sayings. For example, I spirit (should be I was spirited), and homework my (should be my homework).

\section{Lack of Vocabularies}

Data collected through observation showed that the lecturers' difficulties to find the proper vocabulary item when trying to speak English, which reflects their insufficient vocabulary range. In the same way, the data from the interview showed one of the lecturers reported that they actually want to speak, but they did not know the correct word to say.

As claimed by Liu and Jackson (2008, p. 78), based on their study, lack of vocabulary was viewed as a central obstacle for spoken communication by English learners. In the present study, insufficient vocabulary was also described by a lecturer, WS:

"I feel a difference when I write and speak. I mean when writing, it's enough for me to figure out the most suitable words and phrases. But when speaking, some words and phrases may never come to my mind, so my expression may not deliver my intended meaning exactly."

As it is stated by Khan (2016, p. 134), some problems were repeatedly faced by EFL vocabulary learners both with regard to the number of words to be acquired, and the improvement of in-depth semantic understanding of such lexical representations. In other words, how many vocabularies mastered and the meanings of words understood can be influenced by the Bahasa Indonesia' interference when learning English. 
The Interference of Indonesian Language

This was intensely correlated to the previous one, lack of vocabulary. During my observation, I perceived that lecturers tend to speak in Bahasa Indonesia when they discussed the topics I prepared for the discussion. When I asked them about the reason for that in the interview; they explained that they did not have any adequate vocabularies to say. This condition drove them to decide to use Bahasa when they had no idea to express in English. In one of the observations, $\mathrm{K}$, tried to share her childhood as follows:

"I think my childhood is not...really..what, what,..not really menyenangkan hehe.So I want my kids more happy than I am hehe"

The word "menyenangkan" was spoken because S did not know how to say it in English. When K spoke this word, another participant, S, tried to tell that menyenangkan was interesting. This was good response since there was a student-to-student interaction which is very helpful to maintain their ability. This example of her sentences also showed that there was a grammatical error such as word "more happy" which should be happier.

\section{Socio-cultural Problems}

No opportunity to Practice English

"Practice makes perfect". This quote says that when someone wants to acquire a skill, no matter it is, practice is undoubtedly necessary. In language learning, the opportunity to practice is very important. Lantolf and Thorne (2004) explained the significance of peer group as a developmental process of learning occur through participation in cultural, linguistic, and previously formed settings such as family life and peer group interaction. Tok Seng (2006) in his case study of cooperative learning among the secondary school students in Malaysia found that the key informants liked to share their inspirations and information with others and they learned better when a material is explained also by their classmates.

The interview revealed that the institution's less attention to the lecturers' foreign language competence led to unavailable chance to practice English. At IAIN Metro, it is not yet a policy that concerns on encouraging the lecturers to learn a foreign language. This situation makes many lecturers unstimulated to learn a foreign language because the existence of English does not clearly seem necessary in daily academic lives. Among them, there were only a few lecturers who were interested in learning a foreign language.

To respond these problems, the English corner step by step tried to engage the participants with their knowledge of English, the appointed coordinator invited them to become contributing partners in the discussion process. Because according to (Gitterman, 2004, p. 100), education is a trip and 
the coordinator served as a guide or leader. Using their essential expertise and the participants' agreement, the coordinator created opportunities for the lecturers to make their own discoveries and to find their personal meanings. A primary learning function is to structure the lecturers' learning opportunities to interact and familiarize with English and to personally experience the use of English in the discussion.

\section{Interpersonal Problems}

\section{Lack of Confidence}

When the lecturers who did not actively speak English were asked, "why do not you speak English?", they said that they actually wanted to speak but they were not confident. This problem leads to their limited frequency of taking a part in the conversation. One of the lecturers, HM, said that he was shy if people laughed at him because he made mistakes. Whereas, according to Brown (2001, p. 17-29), self-confidence, which he called "I can do it!" principle, is one of twelve principles of language teaching. If the learners firstly believe that they can do the tasks, the self-confidence will encourage them in attaining and accomplishing the tasks. That is one of the keys to become successful in language learning.

This phenomenon was actually common, not only on adult learners but also on young learners. Nguyen and Tuan $(2015$, p. 9) found that confidence was one of the factors affecting the students' speaking performance in a high school. Their students who have lack of confidence tend to be unable to actively speak English and consequently, their speaking performance was low. Therefore, the continuing attempts to build the learners' confidence must be done by the teachers.

\section{Fear of Making Mistakes}

The other problem the adult learners faced was their fear of making mistakes. Some lecturers became anxious because of their perceptions that they would be negatively evaluated by peers. Their shyness made them worried if their speaking was not good. This problem was actually their way to anticipate their mistakes, but it was not correct way since making mistake is a good way to learn a language. Even though this fear is not really influential to their motivation, it negatively affected the lecturers to improve their performance.

A research by Čiček $(2015$, p.5) showed that there was a negative correlation between language anxiety and motivation. The negative, although modest, a relationship was found between language learning anxiety and language achievement. Regarding the language anxiety level among the participants, those who had been learning English for a longer time showed a 
higher level of language anxiety than those who had just started learning English.

\section{DISCUSSION}

The positive perception of the non-English major lecturers or learners on English is a beneficial aspect to support their learning. This is in line with what Ahen (2009) states that perception is a process where someone will form an impression of someone or something. The perception has a significant effect on the students' attitude toward certain matter or objects of attitudes. From this definition, it can be clearly seen that the participants' perception could be benefitted by both instructors and the participants.

Furthermore, Davie and Galloway as cited in Lee, Hoi-yan, and Teresa (2007, p. 5) elaborate the benefits of recognizing learners' perceptions. They believe that this process provides a looked-for model of cooperative working and aids to give the learners' a sense of belonging in their own educational process. Meaning to say, with positive perception, the activities and strategies in English teaching could be well accepted and included in their learning experience.

The desire to participate in better and wider academic society stimulated the lecturers to know more and deepen their knowledge and, more importantly, skill in using English language. This phenomenon is in line with what (Ferrari, 2013, p.2) found that novel insights into L2 motivation from adult learning perspectives, which take into account social participation and leisure participation motives. So, besides wanting to upgrade their self-identity, they expect to have a better position and contribution in their social environment.

This condition seems to prove what Knowles et al., 2005, p. 12) intensely believed that the motivation of adults is internal which involves increased selfesteem and self-actualization. He also believed that when the adults are recognized and appreciated for their individual contributions then they are best motivated to succeed in their learning goals. In the context of this study, the motivation, slowly but regularly, drives the lecturers to keep increasing their skill in speaking English.

This motivation must be kept and increased by some strategies. (Sogunro, 2014, p. 22) investigated several motivating factors of adult learners. Among others are the quality of instruction, quality of curriculum, interactive classroom, progressive assessment and effective academic advising practices. In the context of this study, it is admitted that these factors were not yet accomplished maximally. However, the instructors always try to ensure the lecturers that they are not late to learn English, even on their ages.

Journal on English as a Foreign Language, 8(1), 39-56

Copyright @ 2018 by JEFL, p-ISSN 2088-1657; e-ISSN 2502-6615 
Referring to problems of linguistics specifically on vocabulary mastery, vocabulary knowledge should be a central part of speaking proficiency (Koizumi \& In'nami, 2013). The vocabulary undoubtedly needs to be paid attention. They must have meanings that they are going to express. Subsequently, they need to have a supply of words that they can select from when they wish to express these meanings. If someone wants to describe how he/she feels at this very moment he/she is able to find a word which represents the complexity of their feeling. Therefore, the selection of vocabulary to teach and learn is greatly affected, then, by information, the learners can get about frequency and use. The instructor should access this information from other aspects such as topic, function, structure, teachability, needs and wants.

Also, the phenomenon of using Bahasa Indonesia, and even some participants spoke Javanese language, negatively affected English acquisition. Onike as cited in Patrick, et al. (2013, p. 288) theorized that interference is a psycho-linguistic concept which is a reality in language learning. Errors in second language learning are partly attributable to interference. Theorists of interference are certain of that acquisition of the first language usually disturbs performance in a subsequent language learned.

To minimize these problems, the participants of English corner made the agreement not to use Bahasa Indonesia during the discussion. Unfortunately, these rules were repeatedly violated by some participants. This situation occurred because the problem of lack vocabularies they faced. It was a kind of dilemma that treating the adult learners is different from treating children. Therefore, the instructor so far kept reminding them about the commitment to reduce the use of Bahasa Indonesia or local languages.

In addition, to respond to socio-cultural problems, the English corner step by step tried to engage the participants with their knowledge of English, the appointed coordinator invited them to become contributing partners in the discussion process. Because according to (Gitterman, 2004, p. 100), education is a trip and the coordinator served as a guide or leader. Using their essential expertise and the participants' agreement, the coordinator created opportunities for the lecturers to make their own discoveries and to find their personal meanings. A primary learning function is to structure the lecturers' learning opportunities to interact and familiarize with English and to personally experience the use of English in the discussion.

In relation to the interpersonal problems, in this present study, the participants have lack of confidence but not really affected their motivation. Their confidence got lower when they had no idea to speak. It also decreased when there was a kind of negative response from their peers. Shah as cited in Kameli, Mostapha, and Baki (2012, p. 25) interviewed nine undergraduate ESL 
students in National university of Malaysia using semi-structured questionnaires. One of the socio-cultural factors that she recognized of ESL students was negative peers' reaction and behavior toward practicing the English language among peers. Shah also quoted that "aspects such as inappropriateness in the use of second language, a show of dislike, boastfulness, showing off, and formality second language use are several other factors". She added these factors are considered for the lack of oral communication and practice of second language among students. It can be inferred that a learner's confidence in practicing English is influenced by their friends' attitude toward the practice.

As a consequence, one of ways to increase their confidence was giving the students with materials or tasks from easier level to more difficult one and using appropriate teaching techniques. The learners' ability to do the tasks will stimulate their self-confidence to finish the next tasks. Third, make the students to recognize their own power. It was done by analyzing their strengths and achievement so far in the English corner. By recognizing their own power and ability, the students' self-value and self-esteem will appear in order to build their self-confidence.

About the problem fear of making mistakes, it is as investigated by Tsiplakides and Keramida (2009, p. 41). They discovered that the students found English speaking very daunting because of their speaking anxiety. This anxiety was caused by some problems, particularly the students' fear of negative evaluation from their peers. The lecturers felt shy if they made mistakes in term of pronunciation, misuse of word, unstructured sentences and so on. This was understandable because as the one who was considered an academician, the lecturers faced bigger challenges in reducing their fear of making mistakes, especially when they were asked to practice speaking in front of their colleagues.

In the context of this study, one of the participants, AS, seemed very worried about conveying his opinion when asked about his experience when learning English at junior high school. He said, "emm.. I know ee.. a little. Apa ya, hehe. Oh, my teacher asked to read the text and then I and my friends do..do..what?..do tugas, oh iya, duty". His sayings contained some Indonesian words and several fillers indicating that he was thinking a lot before saying his opinion. The lack of vocabularies and his feeling shy seemed to make his speaking less fluently.

Patil as cited in Boonkit (2010, p. 1306) emphasized that building up the learner's confidence to remove the fear of making errors was a priority that the teacher should deliberate in order to make the learner feel comfortable with their language use. Developing appropriate syllabus design, methods of 
teaching and sufficient tasks and materials can stimulate the learners' confidence and competence in speaking.

\section{CONCLUSION}

English has reached its recognition from many groups of people with a diverse background of education. Not only young learners who are doing their study but also lecturers, people who are generally finished with their learning activities. Even though these adult learners seem to be more able to have good self-management and self-direction, the andragogy instructions should be wellmanaged. In term of speaking English, some lecturers encountered many obstacles such as lack of vocabularies, the interference of Indonesian language, no opportunity to practice English, lack of confidence, and fear of making mistakes. The lecturers and the instructors needed to collaborate well to minimize those problems.

This group of English forum participated by non-English major lecturers should be treated well since it is important to enhance the quality of the lecturers in an Islamic university which is commonly considered less quality than general universities. The activities of learning a foreign language can help the lecturers in broadening their knowledge and presenting their ideas in front of wider and bigger audiences.

It needs to be paid more attention that four vital groups should understand the issues related to and challenges faced by adults lacking Englishspeaking skills. They are policymakers who influence the design, funding, and evaluation of adult English learning programs; researchers who investigate the success of adult education programs; educators who prepare the selected instructors to work with adult English learners; and the instructors themselves.

\section{REFERENCES}

Ahen, J. A. (2009). Students' perception towards English for self-expression. Final Project of Bachelor of Education with honor TESL. Sarawak: Faculty of Cognitive Sciences and Human Development, Universiti Malaysia Sarawak.

Ahmad, S. R. (2016). Importance of English communication skills. International Journal of Applied Research, 2(3), 478-480.

Al Othman, F. H. M., \& Shuqair, K. M. (2013). The impact of motivation on English language learning in the Gulf States. International Journal of Higher Education, 2(4). https://doi.org/10.5430/ijhe.v2n4p123

Aydin, F., \& Yildirim, O. (2017). Foreign language reading strategy use of intermediate level adult Turkish EFL learners. Journal on English as a Foreign Language, 7(2), 135-158. 
Bailey, K. M. (2006). Issues in teaching speaking skills to adult ESOL learners. Review of Adult Learning and Literacy, 6, 113-164.

Boonkit, K. (2010). Enhancing the development of speaking skills for non-native speakers of English. Procedia - Social and Behavioral Sciences, 2(2), 13051309. https://doi.org/10.1016/j.sbspro.2010.03.191

Brown, D. (2001). Teaching by principle. An Interactive Approach to Language Pedagogy (2nd ed.). NY: Longman.

Chinnasamy, J. (2013). Mentoring and adult learning: Andragogy in action. International Journal of Management Research and Reviews, 3(5), 2835-2844.

Čiček, L. (2015). Language learning anxiety-causes and consequences (PhD Thesis).

Cozma, M. (2015). The challenge of teaching English to adult learners in today's world. Procedia - Social and Behavioral Sciences, 197, 1209-1214. https://doi.org/10.1016/.sbspro.2015.07.380

De Vito, K. M. (2009). Implementing adult learning principles to overcome barriers of learning in continuing higher education programs. Online Journal for Workforce Education and Development, 3(4), 1.

Ferrari, L. (2013). The motivation of adult foreign language learners on an Italian beginners' course: an exploratory, longitudinal study (PhD Thesis). University of York.

Gitterman, A. (2004). Interactive andragogy: Principles, methods, and skills. Journal of Teaching in Social Work, 24(3-4), 95-112. https://doi.org/10.1300/067v24n03_07

Grasso, G. M. (2017). Language Anxiety: A study on communication apprehension and willingness to communicate in the older adult EFL learners' context. (B.S. thesis). Università Ca'Foscari Venezia.

Igoudin, A. L. (2008). Adult ESL student motivation for participation in advanced language learning. The CATESOL Journal, 20(1), 27-48.

Kameli, S., Mostapha, G. B., \& Baki, R. B. (2012). The influence of formal language learning environment on vocabulary learning strategies. Journal of Language Teaching and Research, 3(1). https://doi.org/10.4304/1tr.3.1.2329

Khan, M. S. (2016). The impact of native language use on second language vocabulary learning by Saudi EFL students. English Language Teaching, 9(5), 134. https://doi.org/10.5539/elt.v9n5p134

Knowles, M. S., Holton, E. F., \& Swanson, R. A. (2005). The adult learner: The definitive classic in adult education and human resource development (6th ed). Amsterdam๑; Boston: Elsevier.

Koizumi, R., \& In'nami, Y. (2013). Vocabulary knowledge and speaking proficiency among second language learners from novice to intermediate

Journal on English as a Foreign Language, 8(1), 39-56

Copyright (C) 2018 by JEFL, p-ISSN 2088-1657; e-ISSN 2502-6615 
levels. Journal of Language Teaching and Research, 4(5). https://doi.org/10.4304/łltr.4.5.900-913

Lantolf. J, \& Thorne. S. (2004). Sociocultural theory and second language learning. State University Press: The Pennsylvania.

Lauder, A. (2010). The status and function of English in Indonesia: A review of key factors. Makara Hubs-Asia, 8(3).

Lee, Hoi-yan, \& Teresa. (2007). Students' perceptions of learning English through drama: A case study of a Hong Kong class. University of Hong Kong, Pokfulam.

Liu, M., \& Jackson, J. (2008). An exploration of Chinese EFL learners' unwillingness to communicate and foreign language anxiety. Modern Language Journal, 91(1), 71-86.

MacIntyre, P. D. (2001). The convergence of multiple models of motivation for second language learning. Honolulu: University of Hawaii.

Nguyen, H., \& Tuan. (2015). Factors affecting students' speaking performance at Le Thanh Hien high school. Asian Journal of Educational Research, 3(2), $8-23$.

Noor, N. M., Harun, J., \& Aris, B. (2012). Andragogy and pedagogy learning model preference among undergraduate students. Procedia - Social and Behavioral Sciences, 56, 673-678. https://doi.org/10.1016/.sbspro.2012.09.702

Patrick, J. M., Education, M. E. E., \& Sui, M. (2013). Mother-tongue interference on English language pronunciation of senior primary school pupils in Nigeria: Implications for Pedagogy. Language in India 13 (8), 281-298.

Rismayanto, \& Suryani, F. B. (2017). Andragogical orientation: An antimainstream in teaching English to young learners (pp. 157-169). Presented at the The 2nd TEYLIN International Conference. Retrieved from http: //eprints.umk.ac.id /7007 /20/The-2nd-TEYLIN-ilovepdf-compressed166-174.pdf

Sogunro, O. A. (2014). Motivating Factors for adult learners in higher education. International Journal of Higher Education, 4(1). https://doi.org/10.5430/ijhe.v4n1p22

Thornbury, S. (2005). How to teach speaking. London: Pearson Education.

Tok Seng. (2006). Cooperative learning and achievement in English language acquisition in a literature class in a secondary school. Universiti Teknologi Malaysia.

Tsiplakides, I., \& Keramida, A. (2009). Helping students overcome foreign language speaking anxiety in the English classroom: Theoretical issues and practical recommendations. International Education Studies, 2(4), 39. 
Wu, R., Wu, R., \& Le, V. T. (2014). Challenges of adults in learning English as a second language: Focus on adult education in China. Journal of Language Teaching and Research, 5(5). https://doi.org/10.4304/1tr.5.5.1132-1138

\section{Author's Brief CV}

Ahmad Madkur is a teaching staff at English Teaching Department, Faculty of Tarbiya and Teacher Training, State Islamic Institute (IAIN) Metro, Lampung. He accomplished his bachelor in this university in 2012. Then, he gained his master degree in the same major at Islamic State University Syarif Hidayatullah Jakarta in 2015. His research interests cover TEFL and Value Integration in Language Teaching. 